\title{
Three Turkish Composers and Their Paris Education Years
}

\author{
Sirin Akbulut Demirci \\ Department of Music Education, Faculty of Education, Bursa Uludag University, Turkey
}

Copyright $\bigcirc 2018$ by authors, all rights reserved. Authors agree that this article remains permanently open access under the terms of the Creative Commons Attribution License 4.0 International License

\begin{abstract}
The first Turkish musicians who chose composing as a profession were called "The Turkish Five". These composers, listed by their date of birth, were: Cemal Reşit Rey, Hasan Ferit Alnar, Ulvi Cemal Erkin, Ahmet Adnan Saygun and Necil Kazım Akses. These composers squeezed the 500 year music culture of Western music into 30-40 years and made important contributions to Turkish contemporary music. The Turkish five went abroad for education and brought their educational and musical culture heritage back to Turkey. Of Turkish Five, Cemal Reşit Rey, Ulvi Cemal Erkin and Ahmet Adnan Saygun studied in France. In this paper, the years that Ahmed Adnan Saygun, Cemal Reşit Rey and Ulvi Cemal Erkin spent in France were examined with a historical description, and an effort was made to reflect this period. The education they received with intercultural interaction and the contributions of this education to the Turkish Music culture were described.
\end{abstract}

Keywords Turkish Five, Ahmed Adnan Saygun, Ulvi Cemal Erkin, Cemal Reşit Rey, Paris, Education

\section{Introduction}

The "Turkish Five" is the name that was given to the first contemporary Turkish musicians who chose composition as a profession in the period of the establishment of the Turkish Republic. According to their birth years, these musicians were Cemal Reşit Rey (1904-1985), Hasan Ferit Alnar (1906-1978), and Ulvi Cemal Erkin (1906-1972). This period begins on October 29, 1923 and continues to the present day. Since the foundation of the Turkish Republic, Western classical music has been emphasized in Turkey, and many "firsts" in music were achieved during the early years of this period. Meanwhile, the 500-year musical tradition in the West was modeled, and a modern perception of this tradition in musical life was created in only 30 to 40 years. These three composers, Hasan Ferit Alnar (1906-1972), Ahmet Adnan Saygun (1907-1991) and Necil Kazım Akses (1908-1999) were born during the early 1900s. After Ottoman Empire, the new Republic of Turkey was founded, and a new strategy was established for musical policies. Based on this policy, the intention was to mix monophonically structured Turkish music with Western tonality and to create a new type of Turkish music with this Western-polyphonic perspective [2].

The "Turkish Five" were born during the early 1900s. They were the first Turkish musicians who were sent abroad by the government, although there were Ottoman students sent to France for art education in the Tanzimat Period [53]. The founder of the Republic of Turkey, Mustafa Kemal Atatürk (1881-1938), abolished the dervish lodges, where religious music was also performed. Atatürk's musical policy was to embrace and process contemporary European methods to mix with Turkish traditional music and to create a new musical genre that fits into the new concept of the foundational goals of the young Turkish state. For this purpose, musicians were selected and sent abroad with support from the government [2].

On October 29, 1924, the "foreign education" which was planned in accordance with the Education Union Law was implemented by the Board of Education's European Examination. Talented young people who were chosen by these state examinations from 1924 to 1928 were sent to Europe in order to enable the development and creation of contemporary polyphonic music. They had a chance to study in the major art centers of Europe such as Paris, Vienna, Berlin, and Prague. Among the young people returning from their studies abroad, Cemal Reşit Rey who studied in Paris using his own means, and Ulvi Cemal Erkin, Necil Kazım Aksin, Hasan Ferit Alnar, and Ahmet Adnan Saygun, who passed the state examination, constituted the first generation of composers named the "Turkish Five". On the other hand, other first-generation Turkish composers started their musical career with Musiki Muallim Mektebi and at the Istanbul Municipality Conservatory [57]. After they returned to Turkey, they used their knowledge to include western traditions in Turkish folk songs to create a new type of music [2]. Our first-generation composers contributed to the Turkish 
music culture not only as music educators and composers but also as administrators of educational institutions [57].

Current research works of Turkish Five and their compositions show the importance of their period in music history in Turkey [7,10,16-18,34,52,56].

This study is restricted to the education of the three Turkish composers, Ahmet Adnan Saygun, Cemal Reşit Rey and Ulvi Cemal Erkin, in Paris and the reflections of this education in Turkish musical culture.

It is aim to examine the education the three Turkish composers received during this intercultural interaction and the contributions of this education to Turkish Music culture.

It is thought that this work is important in order to present all contributions to the development of the interaction in these cultures.

\section{Materials and Methods}

In this research, the years that these three composers spent in France were examined with a historical description, and an effort was made to reflect this period. It is based on analytical research methods using document analysis as type of qualitative research. Every field can be seen. In the field of education, numerous published studies in scientific journals were identified using document analysis methods $[5,11,13,19,22-25,33,40-43,58-60]$.

\section{Results}

\subsection{Ahmet Adnan Saygun and Paris Education Years}

Ahmet Adnan Saygun was born in Izmir on September 7, 1907. His father was Mehmet Celaleddin (1872-1954) of Nevşehir. His mother was Zeynep Seniha (1887-1925), who came from a family in Konya [4,48,62]. Adnan Saygun's cognitive and mental development was advanced compared to his peers. He learned to read and write with Arabic letters when he was 4, and he solved equations with two unknown variables in the third grade in primary school [62].

Since his father was interested in Sufi music, Saygun took oud lessons with his sister Nabila, who was two years older, with the encouragement of his father. He learned to play the mandolin, and he strengthened his knowledge of Turkish music, mode and rhythm during the lessons he took from Mildan Niyazi Bey [62]. As an outcome of this education, he composed the song 'Maderle Peder Oldu Bahane/ Şevketti Kaza Beni Cihane' (Mother and father became an excuse/God's decree has given me joy in the world), which was his first work. He began solmization lessons with Ismail Zühdü Bey when he was thirteen joining the chorus that Bey managed. He took piano lessons from Rosati, who was his teacher in primary school
(Numune Secondary School music teacher, 1877-1924) $[4,8,62]$.

Ahmet Adnan Saygun learned French by taking private lessons from Amelia Bonal. İzmir was known as "the Paris of the East" at the beginning of the 20th century. The concerts, operettas, operas and the polyphonic choir of Izmir Industry School Band that he listened to, as well as the city, contributed much to his musical education [62]. Because his first piano teacher participated in the War of Liberation, Saygun continued his piano education with the Hungarian Tevfik Bey, and he studied the symphonies of Beethoven together with his teacher using transcriptions for four hands. Saygun was fifteen years old when he graduated from high school in 1922. Although his father found him several jobs, including civil servant jobs, he could not adjust to these, and finally, his father opened a music store for him. Saygun used to play for hours on the piano that he had placed at the rear of the store, and if the customers who came to the store had their instruments with them, he suggested they play and work together. The store fell into bankruptcy within a year, after which Saygun worked at the National Library as a civil servant in 1924 and as a teacher in a school $[4,62]$.

In 1926, he took the examination for the Ankara Music Teacher School. He was appointed as a music teacher for Izmir High School. Saygun translated all the musical terms in the 31 volume La Grande Encyclopedie and Albert Keim's book Wagner's Life and Works into Turkish. He composed a symphony by taking Schubert's B Minor Unfinished Symphony, which he listened to on a gramophone record, as an example. Consequently of the music reforms that were made in 1925 under the leadership of Ataturk, a decision was taken to send young people to conservatories abroad for education. Saygun took an examination for this opportunity in 1928; he passed the examination and went to Paris to study for three years. Adnan Saygun chose Paris because he was fluent in French and Paris was an important center for art [4,62].

Saygun started his education in Paris at the Ecole Normale de Musique. He then transferred to the Schola Cantorum on the suggestion of M. Ragip Gazimihal [62].

Schola Cantorum was established to study Christian church music, as it is understood from its meaning in Latin. Here, Saygun studied important composers such as Palestrina, Bach, Beethoven and Cesar Franck. Despite its conservative character, the Schola Cantorum was the conservatory that gave the best and the soundest musical education in Europe at that time [62]. The French musician Eugene Borrel (1876-1962), who taught at Schola Cantorum, and his wife opened their homes to Saygun and supported him. Borrel's father had worked as a manager in a French posting during the time of the Ottoman Empire, and thus he knew Izmir very well. Eugene Borrel published a series of articles on Turkish music in Revue de Musicologie. At the beginning of his studies, Saygun took harmony and counterpoint lessons from Eugene Borrel. 
Later, he applied to be a student of Vincent d'Indy upon the recommendation of Borrel and was accepted. "Then he gave me permission to attend d'Indiy's course as a student after taking the harmony examination provided that I took counterpoint lessons simultaneously." wrote Saygun to Henri Gulloux in Ankara on May 1st, 1964 [62]. When Adnan Saygun came to Schola Cantorum as d'Indy's student, he was not inexperienced. In contrast, he had passed the entry examinations successfully, and he had acquired sufficient knowledge on the subjects of harmony and counterpoint from the music theory books that he had examined in Izmir, as stated by Sadun Tanju in his notes, p.198 [62].

In addition to the education that Saygun received from d'Indy, he took organ lessons from Edvuard Sourbielle and counterpoint from Paul Le Flem. Accordingly of his music education from childhood and his interest in old music; he conducted research on Gregorian music under the advising of Amede Gastove [4].

In line with the understanding of d'Indy, the school was extremely loyal to tradition, and it was attached to the past with deep respect. We can understand this from these words of Saint-Saens: "Mr. d'Indy is definitely right in defending respect for tradition. Art that is not loyal to tradition is like a rootless tree. He is definitely right in criticizing those who try to be original at all cost." $[4,44]$.

The effects of d'Indy and the school on Saygun are reflected in his own words: "D'Indy made it possible for me to understand and feel the depth of the great works" Armand as cited in [4].I did not come to cancel the ones before me, but to complete them. Completing is not undermining, but making them complete. We indicate the bonds of a son with his mother and father, the bonds of a tree with its roots, and those of a human being with the earth and we understand that no matter how high the head gets, the feet are on the ground and a building cannot be established without a foundation $[4,49]$. These words show that for progress, it is necessary to not severe the ties with the past. Schola Cantorum provided an education that normally takes seven years but Saygun could only stay for three years. Nevertheless, the impact of his education there can be grouped under four main headings. Religious music, Renaissance polyphony and the Baroque counterpoint technique.The model that is reached by starting from Gregorian melodies, Cylclique writing understanding in the works of Gesar Franckin and Folk music

His teacher Le Flem [32] wrote the following in the reference he gave to Saygun: "Not only that he was the most brilliant student of my course, but also he has proven himself in the branch of composition with his strong style and technique." (BUSA, 1964 as cited in [4]).

Although Saygun said that "My writing is very different from the cyclique composition understanding of Cesar Frank", he used the cyclique principle, which he applied accordingly of the education he received at Schola Cantorum, in his Op. 34 First Piano Concerto [4].
Although Saygun went to Europe and studied music there, he never lost his interest in his own music, perhaps because of his longing for his country. In addition, the idea of Borrel that Turkish music should be developed by going to its roots must have influenced Saygun.

"He turned towards the music of his own country and composed his first work, Divertimento, which he listed as Op. 1. This work is like a proof of his longing." [4]. Saygun sent his Op. 1 Divertimento to the composition competition offered as part of the great Colonies Exhibition, of French colonies [55]. After he returned, he was informed that he won the competition [62]. Saygun was appointed as a counterpoint teacher at the Music Teacher School, established in Ankara with the directives of Ataturk. Here, he tried to give the disciplined education, which he had received in Paris to his students. However, the success of the students was seen as insufficient based on examination results. Saygun was given a job in the public houses that were established in 1932. After Saygun returned to Turkey, he was not perceived to be as valuable as he deserved, and he faced many obstacles. So the problems that emerged, Eugene Borrel talked about the value of Saygun to M. Ragip Gazimihal as follows: "Adnan acquired a serious amount of knowledge here, he listened to music, he writes fugue well, and he examined all symphonic music in its most detailed form with all of its useful examples. He has learned to realize bass with the Italian code and to apply orchestral scores to the piano. He also had a lot of organ knowledge that he acquired at Schola. My wife showed him extraordinary and different ways in piano technique and pedagogy. And last, recently he wrote an orchestral piece on the Anatolian themes: this is a composition that is written intricately for orchestra and that has extraordinary ideas in it. If he continues to work seriously, Adnan can compose remarkable works." [21,62].

The games of intrigue played at the Music Teacher School. For this reason Saygun became unemployed in 1934. Ataturk requested that a Turkish opera be composed for the visit of the Iranian Shah to Turkey [36]. Saygun composed his opera Özsoy on a libretto, from a piece in Firdawsi's work Shahnameh in a short period of time, approximately a month, and presented it on stage. The work was presented on stage in front of the Shah of Iran on June 19, 1934 [9].Thanks to this success, Saygun was appointed as the conductor of the Presidential Symphony Orchestra. The opera Taşbebek (Doll), which was presented on stage on December 27, 1934, was also composed upon the request of Ataturk [62].

In 1935, he was removed from this job and appointed to a job in a ministry.

Saygun ensured the invitation of Bartok to Turkey in 1936, and he made some collections of Turkish music with him [62].

Saygun then worked as a composition teacher at the Istanbul Municipality Conservatory until 1939.

In 1946, he was appointed as a composition teacher at 
Ankara Conservatory after the first performance of Yunus Emre Oratorio upon the directive of President Inonu at Paris Pleyel Hall by the Choir Saint-Eustache and Lamoureux Orchestra [50].

Yunus Emre Oratorio was sung in French conducted by Saygun in Paris on March 29, 1947. It received positive reviews and was praised in national and international music circles. Nadia Boulanger also listened to this concert and made positive comments. Thus, Adnan Saygun became a composer who was known outside of Turkey. Saygun used folk music materials in a very raw format. The same style is also seen in Horon, which is the last movement of the Op. 15 Piano Sonatina. He began to compose this work when he returned from Paris, completing it in 1937 [62].

Saygun continued teaching until 1973 when he retired. He then transferred to Istanbul State Conservatory and educated important students like Hasan Uçarsu and Özkan Manav [61].

Saygun passed away on January 6, 1991 [28].

\subsection{Cemal Reşit Rey and Paris Education Years}

He was born to Ahmet Reşit Bey on 25 September 1904 in Jerusalem [50]. His mother was Grand Vizier Ethem Pasha's grandchild Lady Fethiye [3].

"I don't remember how I learned the notes. Who taught me and when are secret things for me. Probably it was my late mother who taught me these." $[6,20,29]$.

The family moved to Paris in 1913, where they were entertained by the major statesmen of the time.

In a period when it was difficult to obtain recorded music, he lived with music by listening to live interpretations, which are the best way to listen to music. When he first went to Paris, The Spring Mass of Stravinsky was being discussed. "We had just arrived in Paris and my late mother took us to Faust's Gounod. The Paris Opera Orchestra is among the major groups of Europe. It is impossible to describe the effect of that orchestra. My first contact with that orchestra happened this way and I have always remembered it." [29,37].

"My father was a good friend of President Poincare. I was around eight and a half years old at that time and I knew the piano through listening. My father wanted to take me to the famous composer and conservatory director Gabriel Faure. Poincase arranged an appointment from Faure for us. You may guess what it means to meet Gabriel Gaure at that age. I will never forget that day all my life." $[26,29]$.

There, he sat at the piano and played some things for Faure that he had learned by listening. Fauree immediately called the famous pedagogue Marguerite Long (1874-1966) and said "Madam, I am sending you a Turkish child, I am not saying anything, you shall see yourself." Faure guessed how Cemal Reşit's future would be. As it was guessed, Cemal Reşit would not do anything other than music in his eighty-one year life [29].
Marguerite Long was a famous piano teacher in Paris. Cemal Reşit became her student in her most productive years. They started their lessons immediately upon the recommendation of Faure. Long registered him at school and she did not accept any material compensation. "On the day that I played my first lesson program, she did something that she rarely used to do in front of the mothers of the students and she hugged me and kissed me." [29, $38,39]$.

With the beginning of the First World War in August 1914, the family immigrated to Geneva, where some of the noble Turkish families of the time were living [27,29].

Cemal Reşit began his formal education in the Geneva Conservatory, in addition to his formal education at St. Antoine College (Conservatoire de Musique de Geneve, Rue Jean Petitot, 8, 1211 Geneva).

Here, he attended the piano lessons of Milhaud and took harmony, counterpoint, organ, fugue and composition lessons from Montillet. He attended the high solfeggio, choir and improvisation lessons of Mademoiselle Lydie Malan. He was presented with a medal from almost every class in this school.

We know that he rose to the virtuoso category at the Geneva Conservatory in 1919 (Bozok, 1963, p.42 as cited in [29]). The family came to İstanbul in 1919. Although he took classes from a family teacher, they were not happy with the teacher and his father, who saw his unhappiness, took him to Paris and had him registered at the conservatory (Gazimihal, 1982 as cited in [29]).He composed a song called Je me demande (I ask myself) and a small operetta entitled Le Petit Chaperon Rouge (Little Red Riding Hood) in 1919 before coming to Paris [29].

In 1920 Madam Long, who was the former piano teacher of Cemal Beg, became a professor at the Paris Conservatory. Cemal Reşit went to her class directly and became a student at the Paris Conservatory. In the meantime, he took music aesthetics classes from Gabriel Faure, who was the director of the conservatory in 1920-1921. Faure left his position as the director of the conservatory in 1920." "Faure taught me the philosophy of music. He used to criticize the works of mine that I played for him, saying "More darkness there, more light here! The orchestra dough is a bit thick here, it should get thinner." [29].

In 1920-1921, Cemal Reşit studied composition, instrumentation and orchestration with Raoul Laparra (1876-1943). Laparra was an important composer of the time. He had studied composition with Faure and Massenet and he won the famous Rome award in 1903. His opera La Habanera was presented at different centers of the world. Cemal Reşit remembers that Laparra warned him against an orchestral structure like that of Faure. Years later, Laparra wrote the following in the score for La Habanera that he signed for Cemal Reşit: "To Cemal Reşit, in whose bright future I believe with all my heart!" [29]. "He studied orchestration with Henri Defosse. He wrote a one act 
dramatic opera Faire sans dire in three years in Paris." $[8,45]$.

When Cemal Reşit came to Paris for the second time, he lived on Keleber Street, near L'Arc de Triomphe. He had a very famous neighbor: Camille Saint-Saens (1835-1921). The composer, who was in his final years, had become a cross old man. "We were neighbors to Saint-Saens, I lived at number seventy-three and he lived at number seventy-five. We had a common bookstore downstairs." $[27,29]$.

Cemal Reşit listened to the last concert of Saint-Saens and admired the great technique and energy he had at that age. The audience reacted so that the artist, who was called to the stage ten times, would not get tired. Cemal Reşit was present at the funeral of Saint-Saens and he remembers that L'Arch de Triomphe was covered with black tulle from the top to the bottom. He conducted the Requiem with tears in his eyes in memory of Faure's teacher [29].

Cemal Reşit listened to the concerts of many famous people who lived in Paris or who visited Paris, and he had the opportunity to evaluate great artists. For example, he heard Rachmaninoff at his recital at the Theatre de Champs-Elysees. He conveyed his impressions as follows: "Until that day I used to find writing nuances such as six fortes in a piano work meaningless and impossible, but I became convinced to the contrary when I was listening to Rachmaninoff. He made such a crescendo at the end of $\mathrm{C}$ sharp minor Prelude that I understood that it is possible to obtain ffff. It was as if the whole Theatre des Champs-Elysees was shaking." [29].

He had a multi-dimensional identity like many artists of that time: he dealt with each branch in which he was educated to an equal extent. Therefore, he was determined to maintain his career as a composer, a pianist and an orchestra conductor.

His first work that was published was İki Melodi (Two Melodies). It was based on two poems of Jean Lahore in French. Two Melodies was published by Rouart et Lerolle in Paris in 1921 (Akay, 1966 as cited in [29]).

In 1922, Cemal Reşit proved himself as a pianist both in Paris and in Istanbul as this was the year in which he was on stage for the first time. In his recital in Paris he played a study and a ballad by Chopin and Gardens in the Rain by Debussy. At the end of that year he also played in the competition of the Marguerite Long class at a concert [29].

1923 opened new horizons for Cemal Reşit and determined the course of his life. Although he had tried composing opera and songs (lieder), these were only played and sung by family members or friends. A song of his was sung professionally for the first time in 1923. The famous French baritone Roger Bourdin (1900-1973), who was from the Opera Comique, sang the song titled $\mathrm{Au}$ Jardin, which Cemal Reşit wrote for voice and piano, at the Ancien Conservatoire. Cemal Reşit was applauded as a composer for the first time. Cemal Reşit also used this hall in his concerts, conducting the Paris Radio Symphony
Orchestra. He conducted the Fatih Senfonisi ve Sazların Sohbeti (Fatih Symphony and the Chat of the Saz) here in 1958 [29].

Cemal Reşit had just graduated from the conservatory when he received a telegram from Uşşakizade Halit Ziya Beg (Istanbul Municipal Council member): "Western music has been added to the Darülelhan board. We reserved the piano and composition classes for you. Please return to the country immediately." There was no limit to the joy of Cemal Reşit, who was nineteen when he received this telegram. "I ran to Madam Long immediately and she said that this was a very bad idea. She shouted saying that teaching, pedagogy etc. would be after I was forty-fifty years old, that I had to get known as a pianist and composer first. Then I left and went to Laparra. The same things!". He got a reaction such as "That's impossible...It's too early for you to teach, it requires the experience of years, you have just graduated, how you can be a teacher without any experience!" Cemal Reşit narrates his determination in this subject as follows: "I did not listen to anybody. I was over the clouds. I took a train and returned to the country. Raoul Rapalla wrote a letter to my father, who was in Nice, France at the time, saying "Save your son." We laughed at that letter together as a family after I returned (İlyasoğlu, 1983 as cited in [29]).

Masude Hanim (1905-2003), who was the first student that he graduated, describes the environment and classes when Cemal Reşit came: "We all listened to music at our homes. We knew Western music as much as Turkish music. However we did not know the depths of the music world until we met Cemal Reşit; he was the one who opened new horizons for us and made it possible for us to get to know the West. He used to give his lectures, sing the songs in their original language and apply the whole orchestra to the piano and play them." The famous "Music Analyses" class started like this [29]. Karlıbel, who was among his last students, always remembers something that Cemal Reşit used to say often: "I attribute great importance to a hadith of Prophet Mohammad: Teach what you know." Cemal Reşit dedicated himself to music and teaching what he knew about music all his life [29]. According to Bülent Tarcan, Cemal Reşit did not impose French music or any other style even though he grew up in the bosom of French music. All students of Cemal Reşit shared a belief about Cemal Reşit: He was a conservatory himself. For Cemal Reşit it was very important for a pianist to memorize immediately the work he/she studies and to play it from memory [29].According to Ertuğrul Sevsay, he was a master class teacher. "He did not tell you what to do, he evaluated what you did." [29].

Cemal Reşit always directed his students according to their talents and capacity and supported them all their lives [29].

In addition to teaching, Cemal Reşit would obtain new compositions for study while he continued his own composition work. With the impact of being at Darülelhan, 
Cemal Reşit started to evaluate the colors that folk art experts presented to him. He took a transcription of twelve Anatolian folk songs to his teacher Raoul Laparra in Paris. Paul Bertrand, who was the director of Editions Heugel, was a close friend of Laparra and the songs were published immediately. He dedicated composition to his teacher Laparra. Later he arranged these compositions for orchestra. They were played by the Pasdeloup Orchestra conducted by Albert Wolff at Mogador Theatre in front of three thousand people in 1926 followed by encores [29]. Cemal Reşit dedicated his piano work, entitled Turkish Scenes on Anatolian Dances Folk Melodies, which he composed later, to the French pianist Alfred Cortot. Bebek Senfonik Şiiri (Baby Symphonic Poem), which he composed later on, was played by the Pasdeloup Orchestra conducted by D.E. Ingelbrecht at the Theatre des Champs-Elysees of Paris on December 29 [29]. Cemal Reşit proved himself as a pianist and composer after the Baby Symphony. Alfred Cortot, who was a famous pianist at the time, gave a recital at the French theatre in Istanbul in January 1928. At the end he played a piece by Cemal Reşit and he presented it as follows: "Now I will play a piece from a Turkish composer. France is hopeful of the future that composer Cemal Reşit, who is the composer of this work, promises." [29]. Cortot established an orchestra in Paris in 1930. The distinguishing feature of this orchestra was that all of its members were virtuoso interpreters. Cortot requested a work from Cemal Reșit for the orchestra to play Enstantaneler (Snapshots) was the result. Enstantaneler, which had the sub-heading "Impressions for orchestra", comprised five sections. Enstantaneler were played by the orchestra of Ecole Normale de Musique in Paris in 1932 and conducted by Cortot. Cemal Reşit played the piano in the section entitled Empty Mosque Courtyard. Dimitri Mitropoulos conducted the Chromatic Concerto, played by the Paris Symphony Orchestra at Pleyel Hall on March 12, 1933; again the soloist was Cemal Reşit Rey [29]. Famous composer Alban Berg (1885-1995) come backstage and congratulated Cemal Reşit saying "I did not know that such advanced music was written in Turkey." [29].

Finally let us summarize Cemal Reşit with the words of Bülent Tarcan: "Let us not try to discuss composer Cemal Reşit Rey here. Music history shall tell his real value and meaning much better than us. However no one can deny the fact that Cemal Reşit Rey is a person who produced great works at the international scale with the Western technique." [29].

Cemal Reşit Rey died on October 5, 1985 [30].

\subsection{Ulvi Cemal Erkin and Paris Education Years}

Erkin was born on 14 March 1906 in İstanbul [28]. His father was Mehmed Cemal Bey [46,47] and his mother was Lady Nesibe [15].

He passed the examination of the Ministry of National
Education in 1925, which was organized to select students to be sent to Europe for musical education. He went to Paris, which was among the prominent cultural and artistic centers of Europe. He adapted to Paris quickly because he had an advantage due to his being a graduate of Galatasaray High School, which offered education in French. However he had to focus on his piano studies professionally. Therefore, he took private lessons for two years before entering the conservatory. He was accepted to the Paris Conservatory as the result of a difficult examination. $\mathrm{He}$ studied with different teachers after passing this examination. He studied piano with Isıdor Philip and Camille Decreus. He changed his school after the Paris Conservatory and transferred to the Ecole Normale de Musique [31]. Here he studied harmony with Jean Galon and counterpoint with his brother Noel Gallon. The teacher that he learned the most from was Nadia Boulanger, who was the most famous composition teacher of the time. Boulanger conducted the symphony orchestras in London, Boston, New York and Philadelphia as the first woman orchestra conductor. She was a student of the famous composer Gabriel Faure [14,31].

Ulvi Cemal Erkin obtained his license diploma after passing a difficult examination following his studies at the Paris Conservatory and a five year period of study at the Ecole Normale de Musique. This ended his student life. The success of Ulvi Cemal, which was different from and superior to all his friends, was narrated with praise in the music journal Monde Musical [14, 31].

Ulvi Cemal then returned to Turkey. He was appointed as a piano and harmony teacher at the Music Teacher School at the beginning of the academic year in 1930. He was the first person who was educated in Europe and returned to a job at this institution. In those years, Turkey was at the beginning stages in terms of music. The only orchestra, which was affiliated with the President's office, offered a few concerts under the baton of Zeki Üngör. There was no opera yet. In this environment, Ulvi Cemal composed İki Dans (Two Dances), which was his first composition and the piece Ninni, Emprovizyon ve Zeybek (Lullaby, Improvisation and Zeybek), for violin and piano which he started in Paris and finalized in Turkey. He began to be known from the concerts that the Music Teacher School offered. Starting from the days when Ulvi Cemal began to teach, he sometimes played a piano piece in front of the orchestra, sometimes accompanied his friends on piano and sometimes he played his own works. He passed his teaching years with an intensive tempo. On March 6, 1931, he played a piano concerto of Mozart with an orchestra for the first time in his life. He performed the Symphonic Variations of Cesar Frank on December 30, 1932. Meanwhile he composed five small piano pieces, which he named Beş Damla (Five Drops). Five Drops is the first composition of Ulvi Cemal that was published, and it received much positive reaction both in the national and international media. Ulvi Cemal composed the piano piece 
Konçertino in the romantic period when he met his wife [31].

Ulvi Cemal composed an orchestral work named Bayram (Festival), which was three minutes long, four years after he returned from Europe, when he was only 28 years old. Bayram was first played by the Presidential Philharmonic Orchestra in Ankara under the baton of Ulvi Cemal in 1934. It was performed by the Moscow Philharmonic Orchestra in Baku two months later. Ulvi Cemal conducted his own work for the first time with this work, and this was the first Turkish symphony that was played abroad [31].

Ulvi Cemal realized another first after Bayram by composing a String Quartet, which was the first chamber music from Turkey. He started to compose the work in 1935 and completed it a year later. It was performed at the hall of the Ankara State Conservatory twice in a row. The same concert was broadcast on Ankara Radio [31].

In 1943 Ulvi Cemal submitted two compositions to the competition that was organized within the scope of the works of the Republican People's Party to support art, Karagöz and Piano Concerto. He won the competition with Piano Concerto. Ulvi Cemal decided to compose this work upon the suggestion of Alfred Cortot, who came to Turkey to give a concert, and he dedicated it to his wife $[15,31]$.

The First Symphony of Ulvi Cemal was added to the program of the Prague Music Festival one year after it was played for the first time. He was invited to the performance as the composer. The Prague Philharmonic Orchestra, which had 120 members, interpreted the work successfully under the baton of Ulvi Cemal, with five curtain calls following the enthusiastic applause of the audience after the performance [31].

The First Symphony of Erkin was the first work that was played abroad and the Second Symphony was the first symphony that was recorded in Turkish musical history. It was played for the first time by the Munich Philharmonic Orchestra conducted by Karl Oehring on July 2, 1958, and it was broadcast on Bavaria Radio. Three years later, it was played in America under the baton of Henry Swoboda and it was played in Turkey on February 13, 1962 [15,31].

Ulvi Cemal processed the pure intact lullabies of Anatolia, its requiems, and its folk songs, that told of intense love stories. They appeal with a universal power of narration without spoiling their unique beauty. The composer adopted folk music in all of its aspects and used them in his compositions as building blocks by analyzing their style, character and techniques.

Ulvi Cemal was awarded four medals during his lifetime: one of them was from Italy and three of them were from France [31].

The first medal was "Palme Academique", which was awarded by the French Ministry of Education on April 12, 1950.

The second medal was the "National Merit Medal", "Legion D'honneur" medal at the level of "Knight", which France gave on March 21, 1959.
The third medal was the "Ordine Al Merito Della Repubblica İtaliano" medal at the level of "Ufficiale", which Italy awarded on December 27, 1963.

The fourth medal was the "Officer" medal, which was a higher-level medal then the national merit medal Legion D'honneur, and which was awarded on December 23, 1970.

Ulvi Cemal's health began to fail at the beginning of the 1970s. He passed away on September 15, 1972 [15,31].

\section{Conclusions}

When we examine the education of the first Turkish composers in France, the following conclusions may be drawn:

All of the composers received a very high-quality education and developed themselves.

They experienced the positive effects of being in the cultural music environment of Paris.

After they returned to Turkey, they all contributed to music education in Turkey as teachers. The greatest problem in music education of the Ottoman period was the lack of qualified music educators [35].

All three had an important place in Turkish music culture as composers $[7,10,12,16-18,34,52,56]$.They became known as composers both in Turkey and abroad.

"The first generation of Turkish composer, without living in Europe's development stages in the polyphonic music of the last 500 years, found themselves in 20th century music. This means that their knowledge of Europe's 500-year development process had to fit in a short period of time $20-30$ years." $[15,51]$.

These three composers brought the first in many developments in Turkish music: the first symphony, the first piano concerto, the first string quartet, the first ethnomusicology research, the first publication of notes, the first recording of compositions, and so on.

Finally, it should not be forgotten that these composers expended much effort and worked hard to bring the Western music culture of 500 years to Turkey in the short period of time of approximately 35 years.

\section{Acknowledgements}

This study was presented as an oral presentation and published in abstract the book of the 1st Annual International Conference on Fine and Performing Arts, held on 7-8 June 2010 in Athens, Greece.

\section{REFERENCES}

[1] Akbulut, Ş. (2010, June). Three Turkish composers and Paris education years. Paper presented at the First Annual 
International Conference on Fine and Performing Arts, Athens, Greece. Abstract retrieved from http://www.atiner.gr/abstracts/2010ABST-ART.pdf

[2] Akbulut, Ş. (2011). "Turkish Five": Their Contributions to Contemporary Piano Music and Piano Education in Turkey. US-China Education Review, 8 (3), 354-369.

[3] Andak, S. (1969, April 13). Ölümünün 10. y1ldönümünde Cemal Reşit Rey ağbeyi Ekrem Reşit'i anlatıyor (On the 10th anniversary of death, Cemal Reşit Rey is telling his brother Ekrem Resit Rey), Retrieved from http://earsiv.sehir.edu.tr:8080/xmlui/bitstream/handle/1149 8/25648/001514020006.pdf?sequence=1 , p.6.

[4] Arıcı, E. (2007). Ahmet Adnan Saygun Doğu-Batı arası müzik köprüsü (Music bridge between east-west Ahmet Adnan Saygun) (2nd ed.). İstanbul: Yap1 Kredi Publishing.

[5] Arık, R.S. ve Türkmen, M. (2009). Examination of articles in scientific journals published in the field of educational sciences (Eğitim bilimleri alanında yayınlanan bilimsel dergilerde yer alan makalelerin incelenmesi). Paper presented at the First International Congress of Educational Research, Çanakkale, Turkey. Retrieved from oc.eab.org.tr/egtconf/pdfkitap/pdf/488.pdf

[6] Arın, S. (Reporter). (n.d.). Bilgeler ve ustalar (Sages and masters) [Television movie]. İş Banks Archives.

[7] Ayas, O.G. (2016). Turkish Music Reform and Russian Model: Discssion from the viewpoint of music sociology (Musiki İnkilabı ve Rus Modeli: karşılaştırmalı müzik sosyolojisi açısından bir tartışma). Bilig Journal, 77, 131-155.

[8] Aydın, Y. (2003). Türk Beşleri (Turkish five). Ankara: Music Encyclopedia Publications.

[9] Aydın, Y. (2004). Ahmet Adnan Saygun'un yaşam öyküsü ile besteci ve müzikolog kimlikleri (Ahmed Adnan Saygun's life story and composer and musicologist identities). In Biography 5: Ahmed Adnan Saygun (pp.21-67). Ankara: Bağlam Publishing.

[10] Aytüre, G.G. (2017), Reflections of Turkish modernization of the Republican period on violin concert of Turkish Five (Cumhuriyet dönemi müzik modernleşmesinin Türk Beşleri'nin keman konçertolarına yansımaları) (master's thesis). Başkent University, Social Science Institution. http://acikerisim.baskent.edu.tr/handle/11727/2771

[11] Bacanak, A., Değirmenci. S., Karamustafaoğlu, S. \&Karamustafaoğlu, Ö. (2011). Science Education Publications Published in E-Journals: Method Analysis (E-dergilerde yayınlanan fen eğitimi makaleleri: yöntem analizi). Journal of Turkish Science Education, 8 (1), 119-132.

[12] Canal, D.-A. (1987), Ahmed Adnan Saygun in Paris, Ahmed Adnan Saygun Seminar Proceedings (ed. T. Göğüş, pp. 28-30). İzmir: Izmir Philharmonic Association Publications.

[13] Cavanaugh, C.S. (2001). The effectiveness of interactive distance education technologies in $\mathrm{K}-12$ learning: A meta-analysis. International Journal of Educational Telecommunications, 7, 73-88.

[14] Çalgan, K. (n.d.). Ulvi Cemal Erkin Duyuşlar'dan Koçekçe'ye (Ulvi Cemal Erkin from Duyuşlar to Köçekçe). Ankara: Sevda-Cenap and Music Foundation Publishing.
[15] Çalgan, K. (2001). Duyuşlar Ulvi Cemal Erkin (2nd ed.). Ankara: Music Encyclopedia Publications.

[16] Demirel. E (2015). Re-localization as a postmodern trend from contemporary Turkish composers (Çăgdaş Türk Bestecilerinde postmodern bir eğilim olarak yeniden yerellik). Education Science, 10 (2), 84-99.

[17] Deniz, Ü. (2015). Milli Musiki ve Türk Beşleri (National Music and Turkish Five). Ankara: Gece Publishing.

[18] Dindar, S. (2013). Solo flute works of Turkish composers in antinomy of modernity and tradition (Çağdaşlik ve geleneksellik antinomisinde Türk bestecilerinin solo flüt eserleri). Retrieved from space.deu.edu.tr

[19] Elmore, P. B., \& Woehlke, P. L. (1998). Twenty years of research methods employed in American Educational Research Journal, Educational Researcher and Review of Educational Research. (ERIC Document Reproduction Service No. ED420701).

[20] Ersel, H., Koloğlu, D. \&Pınar, A. (2014). 100. doğum y1lında Cemal Reşit Rey "100. Doğum yılında Açık Radyo'da Cemal Reşit Rey özel programı” (Cemal Reşit Rey in the 100th birth year "Cemal Reşit Rey in the $100^{\text {th }}$ birth year special program at Açık Radio). İstanbul: Pan Publishing.

[21] Gazimihal, M.R. (1935). Ahmed Adnan. Music and Art Movements, (10), 6-8.

[22] Geçit, Y., (2010). A research on studies on social studies education curricula (Sosyal bilgiler eğitimi öğretim programları konulu çalışmalar üzerine bir araștırma), 9. National Classroom Teacher Education Symposium, Book

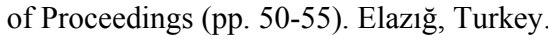

[23] Ginsburg-Block, M. D., Rohrbeck, C. A., \& Fantuzzo, J. W (2006). A meta-analytic review of social, self-concept, and behavioral outcomes of peer-assisted learning. Journal of Educational Psychology, 98, 732-749.

[24] Goodwin, L. D., \& Goodwin, W. L. (1985). Statistical techniques in AERJ articles, 1979- 1983: the preparation of graduate students to read the educational research literature. Educational Researcher, 14(2), 5-11.

[25] Gülbahar, Y., \& Alper, A. (2009). A content analysis on researches made in the field of teaching technologies, (Öğretim teknolojileri alanında yapılan araştırmalar konusunda bir gçerik analizi), Ankara University Journal of Educational Sciences, 42 (2), 93-111.

[26] İlyasoğlu, E. (Reporter). (1982). Bestecilerimizle söyleşiler (Interviews with our composers) [TRT Radio Program].

[27] İlyasoğlu, E. (1997). Cemal Reşit Rey müzikten ibaret bir dünyada gezintiler (Cemal Reşit Rey trips to the world consisting of music). İstanbul: Yap1 Kredi Publishing.

[28] İlyasoğlu, E. (1998). Çağdaş Türk bestecileri contemporary Turkish composers. İstanbul: Pan Publishing.

[29] İlyasoğlu, E. (2005). Cemal Reşit Rey müzikten ibaret bir dünyada gezintiler (Cemal Reşit Rey trips to the world consisting of music).İstanbul: Dünya Publishing.

[30] Kolçak, O. (2006). Cemal Reşit Rey. İstanbul: Kastaş Publishing.

[31] Kolçak, O. (2008). Ulvi Cemal Erkin. İstanbul: Kastaș Publishing. 
[32] Le Flem, P. (1964). Reference for Adnan Saygun. Ankara: Bilkent University Ahmet Adnan Saygun Music Education and Research Center.

[33] Mee, T.M., Lan, O.S. \& Chin, L.H.(2009). Statistical techniques employed in education theses in Malaysia. European Journal of Social Sciences. 12(2), 269-276.

[34] Munzur, M. (2013). The form analysis of the violin concerto by Ulvi Cemal Erin in terms of structural studies. Journal of Education and Future. 4, 123-128.

[35] Özden, E. (2015). Music in the Ottoman education and training system (Osmanl Maarif'inde Musiki). Ankara: Atatürk Culture, Language and History High InstitutionTurkish History Institution Publications.

[36] Refiğg, G. (2012). Atatürk ve Adnan Saygun (Atatürk and Adnan Saygun). İstanbul: Boyut Publising.

[37] Refiğ, H. (Director). (1973). Yetmișbeș yașında orchestra bassinda (At the age 75 in front of the orchestra) [Television documentary]. Mimar Sinan University Archives of Radio and Television Institute.

[38] Rey, C.R. (1966). Marguerite Long. Orkestra Journal, 36.

[39] Rey, C.R. (2007). "Orkestra" Yazılarl ("Orkestra" Articles). İstanbul: Pencere Publishing.

[40] Ritter, G.W., Barnett, J.H., Denny, G.S., \& Albin, G.R. (2009). The effectiveness of volunteer tutoring programs for elementary and middle school students: a meta-analysis. Review of Educational Research, 79, 3-38.

[41] Rohrbeck, C. A., Ginsburg-Block, M. D., Fantuzzo, J. W., \& Miller, T. R. (2003). Peer assisted learning interventions with elementary school students: a meta-analytic review. Journal of Educational Psychology, 95, 240-257.

[42] Roseth, C.J., Johnson, D.W. \& Johnson, R.T. (2008). Promoting early adolescents "achievement and peer relationships: the effects of cooperative, competitive, and individualistic goal structures. Psychological Bulletin, 134 (2), 223-246.

[43] Sabatino, D. A. (1981). A 5 year analysis of four selected special education periodicals. The Journal of Special Education, 15 (3), 373-388.

[44] Saint-Saens, C. (1919). The ideas of M. Vincent d'Indy. Paris: Edition Pierre Lafitte.

[45] Say, A. (1985). Cemal Reşit Rey, Music Encyclopedia (Vol.4, pp.1085-1087). Ankara: Music Encyclopedia Publications.

[46] Say, A. (1995). Müzik Tarihi (Music History) (2nd ed.). Ankara: Music Encyclopedia Publications.

[47] Say, A. (1998). Türkiye'nin Müzik Atlası (The musical atlas of Turkey). İstnabul: Borusan Publishing.

[48] Saydam, A. (1997). Ünlü müzisyenler (Famous musicians) (4th ed.). Ankara: Arkadaş Publishing.

[49] Saygun, A.A. (1949). Düşüp kalkmalar geçer, yol değişmez (Fall down and get up passes, the road does not change). Şadırvan, 12, 4.

[50] Selanik, C. (1996). Müzik sanatının tarihsel serüveni (Historical adventure of musical art). Ankara: Doruk
Publishing.

[51] Sevda-Cenap and Music Foundation (n.d.). Ahmet Adnan Saygun çokseslilik meşalesi (Polyphony torch Ahmet Adnan Saygun). Ankara: Sevda-Cenap and Music Foundation Publishing.

[52] Subaşı, E., Nalbantoğlu, E., Uralçın, N., Atılgan, S.Z. \& Çetin, S. (2017). Turkey towards a revolution in contemporary music: Music Turkish Five (Çağdaş Türkiye yolunda bir müzik devrimi: Müziğin Türk Beşleri). Student Project Bilkent University, Department of History. Retrieved from http://repository.bilkent.edu.tr/handle/11693/34005?show= full

[53] Şişman, A. (2004). The Ottoman students who were sent to France during the Tanzimat Period (1839-1876) (Tanzimat Döneminde Fransa'ya gönderilen Osmanlı öğrencileri 1839-1876). Ankara: Atatürk Culture, Language and History High Institution- Turkish History Institution Publications.

[54] Tanju, S. (1996). Eski dostlar (Old friends). İstanbul: İnkilap Bookstore.

[55] Tanju, S. (2012). Adnan Saygun'larda Çay Sohpetleri (Tea conversations at Adnan Saygun's). İstanbul: Pan Publishing.

[56] Tarkum, E (2017). Examination of the formation and development process of contemporary Turkish music and the factors that play this process (Çağdaş Türk Müziğinin oluşum ve gelişim sürecinin ve bu süreçete rol oynayan faktörlerin incelenmesi). Trakya University Journal of Social Science, 19 (2). 247-260.

[57] Tunçdemir, İ. (2007, September). Cumhuriyet dönemi müzik kültürünün oluşmasinda rol oynayan sanatçilarimiz ve Türk müziğine katkilari (the artists who have rols and involved in the formation of music culture in music culture republican period and contributions to Turkish music. Paper presented at 16th National Congress of Educational Sciences, Tokat, Turkey. Paper retrieved from http://www.muzikegitimcileri.net/bilimsel/bildiri/I-Tuncde mir_7.pdf

[58] West, C. K., Carmody, C. \& Stallings, W. M. (1983). The quality of research articles gn the journal of educational research, 1970 and 1980. Journal of Educational Research, 77 (2), 70-76

[59] Willson, V.L. (1980). Research techniques in AERJ articles: 1969-1978. Educational Researcher, 9 (6), 5-10.

[60] Yalçın, N., Bilican, S., Kezer, F. \& Yalçın, Ö. (2009) Hacettepe University Education Faculty magazine, The quality of published articles: content analysis (Hacettepe Üniversitesi Eğitim Fakültesi Dergisi'nde yayınlanan makalelerin niteliği: içerik analizi). Paper presented at the First International Congress of Educational Research, Çanakkale, Turkey. Retrieved from http://oc.eab.org.tr/egtconf/pdfkitap/pdf/453.pdf

[61] Yedig, S (2012). Anılardaki Adnan Saygun (Adnan Saygun in memories). İstanbul: Pan Publishing.

[62] Yıldız, D. (2007). Doğumunun 100.y1lında Ahmet Adnan Saygun (Ahmed Adnan Saygun at the 100th birthday). Ankara: Sun Publishing. 